\title{
In Memoriam: Bert Peeters
}

C'est avec une profonde tristesse que le comité des rédacteurs de la revue fait part du décès de l'un des siens, le 22 février 2021. Collègue estimé de tous, Bert Peeters fut Honorary Associate Professor à l'Université Nationale d'Australie, Professeur Adjoint à l'Université Griffith, et Gastprofessor à l'Universiteit Antwerpen. Ses neuf ans de service en tant que Editeur des Comptes-rendus pour le Journal of French Language Studies, sa collégialité exemplaire et sa diligence à assurer des résultats rédactionnels de la plus grande qualité ont marqué la revue à jamais. Une notice nécrologique plus compète paraîtra dans le prochain numéro.

It is with great regret that we announce the death of one of our associate Editors, Bert Peeters, on 22 February 2021. Honorary Associate Professor at the Australian National University, Adjunct Associate Professor at Griffith University, and Gastprofessor at the University of Antwerp, Bert was a valued colleague who served on the board of the Journal of French Language Studies as Book Review Editor for nine years. His fellow editors will deeply miss his contributions to a collegial working environment and his diligence in ensuring the high standards of the journal from an editorial perspective. A full obituary will appear in a future issue of the journal.

Cite this article: In Memoriam: Bert Peeters. Journal of French Language Studies 31, 1. https://doi.org/ $10.1017 /$ S0959269521000053 